\title{
HYPERPYREXIA IN ASSOCIATION WITH GENERAL ANAESTHESIA IN CHILDREN
}

\author{
J. E. S. Retton, M.B., B.S., F.F.A.R.C.s. (ENG.), R. E. CReighton, M.D., F.R.C.P.(c), \\ A. E. Johnston, M.D., C.M., F.R.C.P.(C), D. A. PELTON, M.D., F.R.C.P. (C), AND \\ A. W. CoNN, M.D., B.SC.(MED.), F.R.C.P.(C) ${ }^{\circ}$
}

\section{INTRODUCTION}

HYPERPYREXIA is a rare complication of general anaesthesia. The occurrence and severity of the condition were first brought to our attention by Stephen. ${ }^{1}$ Recently, Saidman, Havard, and Eger ${ }^{2}$ reported two cases in which hyperpyrexia occured during general anaesthesia, one with fatal outcome; others have been reported as well. 8,4

This paper describes three cases which occurred at the Hospital for Sick Children, Toronto, in the period June 1964 to December 1965, during which time 24,431 general anaesthetics were administered. In each case the patient developed hyperpyrexia associated with marked skeletal muscle rigidity during general anaesthesia. There was one death in the operative period.

\section{CASE I}

A three-year-old female child weighing $19.2 \mathrm{Kg}$. was admitted in June 1964 with a tentative diagnosis of arthrogryposis. She exhibited poor muscular development with marked flexion contractures of all extremities, and a moderate degree of thoraco-lumbar scoliosis. Past history revealed that one year previously she had undergone incision and drainage of an abscess uneventfully under general anaesthesia. The agents used on that occasion were atropine, nitrous oxide, oxygen, and halothane. After routine investigations, the patient was scheduled for a bilateral tendo-achilles lengthening and muscle biopsy.

On the day of operation, atropine $0.3 \mathrm{mg}$. was given intravenously thirty minutes preoperatively. Anaesthesia was induced with nitrous oxide, oxygen (6:3 litres/minute), and halothane (0.5-2.0\%), using a face mask and a modified Ayre's T-piece circuit. The patient's heart rate was $\mathbf{1 7 0}$ per minute, systolic blood pressure was $130 \mathrm{~mm}$. Hg at induction.

Four minutes after induction, succinylcholine $15 \mathrm{mg}$. was administered intravenously to facilitate intubation. Within thirty seconds there occurred a severe, sustained, generalized contraction of all skeletal muscles. This resulted in a marked fixation of the abdominal wall, chest cage, and jaw. An additional $65 \mathrm{mg}$. of succinylcholine, in divided doses, was given intravenously over a period of ten minutes with no apparent reduction in the degree of muscular spasm. Ventilation throughout this period was maintained with positive pressure through a

-Department of Anaesthesia, the Hospital for Sick Children, Toronto. 
face mask. The jaw was opened, the patient intubated, and anaesthesia was maintained with oxygen and halothane with controlled respiration. The operative procedure was then carried out.

Seventy minutes after induction, the rectal temperature was $40^{\circ} \mathrm{C} .\left(104^{\circ} \mathrm{F}.\right)$, and ice bags were placed on the patient. Ten minutes later, after she had been transferred to the plaster room, the temperature was $41.9^{\circ} \mathrm{C}$. $\left(107.4^{\circ} \mathrm{F}\right.$.), and the heart rate had reached 200 per minute. Active measures to lower the temperature were instituted, including fans, alcohol, ice-water sponging, and the application of ice packs. Ninety-five minutes after induction the patient began to make weak respiratory efforts. The heart rate had fallen to 185 per minute and the temperature was $39^{\circ} \mathrm{C}$. $\left(102.2^{\circ} \mathrm{F}\right.$.). The patient was returned to the recovery room one hundred and ten minutes after induction. Her temperature was now $35.8^{\circ}$ C. $\left(96.8^{\circ}\right.$ F.), heart rate 160 per minute, and blood pressure 100/70. Because of inadequate ventilation, her respiration was controlled by a pressurelimited respirator via the endotracheal tube. One hundred and fifty minutes after her induction, her muscles had returned to a normal degree of tonus, her ventilation was adequate, and extubation was performed.

The patient remained well until the third post-operative day, when she developed pneumonia and other complications. She was discharged on the sixty-seventh post-operative day.

\section{CASE II}

A five-year-old healthy male child weighing $19.5 \mathrm{Kg}$. was admitted for surgical correction of strabismus. He had previously undergone two uneventful eye operations.

At operation, atropine sulphate $0.3 \mathrm{mg}$. was given intravenously and the patient was induced with sodium thiopentone $100 \mathrm{mg}$. Following the intravenous administration of succinylcholine $20 \mathrm{mg}$, sustained generalized skeletal muscle contraction occurred. An additional dose ( $30 \mathrm{mg}$.) failed to produce any relaxation, and no respiratory movements occurred in association with the hypertonicity. Despite mild laryngospasm it was possible to ventilate the lungs using a face mask and bag. Respiratory movements commenced twenty minutes after induction and gradually increased. Intubation was not attempted.

The generalized muscle hypertonicity subsided slowly and respiration was judged to be satisfactory thirty-five minutes after induction. Surgery was deferred. When the patient was transferred to the recovery room the rectal temperature was $38.3^{\circ}$ C. $\left(101^{\circ}\right.$ F.). Fifteen minutes later, the rectal temperature was $38.7^{\circ} \mathrm{C}$. $\left(101.6^{\circ} \mathrm{F}\right.$.) and in a further ten minutes the patient became conscious and the pyrexia began to subside. Arterial blood gas analysis (rectal temperature $37.3^{\circ} \mathrm{C}$.) showed a $\mathrm{pH}$ of $7.21, \mathrm{P}_{\mathrm{CO}_{2}}$ of $21 \mathrm{~mm}$. $\mathrm{Hg}$, and a base excess of -15.5 $\mathrm{mEq} . / \mathrm{L}$. The patient made a complete recovery.

As in Case I, succinylcholine was considered to be the cause of the abnormal muscular response. The postanaesthetic pyrexia was thought to be incidental. Operation was postponed for $\mathbf{4 8}$ hours and it was decided that muscle relaxants would be omitted.

For the second procedure atropine sulphate $0.3 \mathrm{mg}$. was given intramuscularly 
40 minutes preoperatively. The patient was induced with methohexitone $40 \mathrm{mg}$. intravenously, and anaesthesia was maintained with a nitrous-oxide-oxygenhalothane mixture using a Magill circuit and Stephen-Slater valve. The patient was intubated five minutes after induction without difficulty. An E.K.G. was connected for visual and auditory monitoring in addition to a pre-cordial stethoscope, blood-pressure cuff, and rectal thermometer.

Anaesthesia continued uneventfully until twenty minutes after induction when it was observed that the pupils were moderately dilated and the heart rate was 140 per minute. The skin was warm and flushed and the rectal temperature was $37.2^{\circ} \mathrm{C} .\left(98.9^{\circ} \mathrm{F}.\right)$.

The operation was completed forty-five minutes after induction of anaesthesia. At this stage, it was noticed that there was a generalized increase in muscle tone; the rectal temperature was $37.6^{\circ}$ C. $\left(99.7^{\circ}\right.$ F.) and a tachypnoea of 60 per minute had developed. The pupils remained moderately dilated and there was cutaneous piloerector activity.

Within five minutes the rectal temperature had risen to $38.2^{\circ} \mathrm{C}$. $\left(100.8^{\circ} \mathrm{F}\right.$.) and arterial blood gas analysis showed a $\mathrm{pH}$ of $7.02, \mathbf{P}_{\mathrm{CO}_{2}}$ of $77 \mathrm{~mm}$. $\mathrm{Hg}$, and a base excess of $-15.5 \mathrm{mEq} . / \mathrm{L}$. An intravenous infusion of 5 per cent dextrose in water was started and $50 \mathrm{mEq}$. of 5 per cent sodium bicarbonate was given intravenously.

Thirty minutes after the operation was completed the rectal temperature was $40.5^{\circ} \mathrm{C} .\left(104.9^{\circ} \mathrm{F}\right.$.). In spite of active cooling with alcohol sponges and fans the temperature continued to rise. Approximately ten minutes later consciousness returned and the rectal temperature reached a peak of $41.5^{\circ} \mathrm{C}$. $\left(106.7^{\circ} \mathrm{F}\right.$.). During the subsequent hour the muscular rigidity gradually subsided and the rectal temperature fell to normal. The patient made a satisfactory recovery.

\section{CASE III}

A ten-year-old healthy female weighing $39.9 \mathrm{Kg}$. was admitted with a diagnosis of idiopathic thoraco-lumbar scoliosis. There was no significant respiratory impairment. At two years of age, an ethyl-chloride-ether-oxygen anaesthetic had been administered uneventfully for the repair of an umbilical hernia. The patient was now scheduled to undergo spinal fusion and Harrington rod instrumentation.

On the day of operation, pentobarbital $80 \mathrm{mg}$., pethidine $50 \mathrm{mg}$., and atropine $0.3 \mathrm{mg}$. were given intramuscularly 45 minutes preoperatively. Anaesthesia was induced with sodium thiopentone $200 \mathrm{mg}$. followed by succinylcholine $40 \mathrm{mg}$. intravenously. No muscle relaxation occurred and a generalized muscle hypertonicity developed. It was difficult to open the mouth for laryngoscopy and intubation, but ventilation was possible using a bag and face mask. In the following ten minutes two injections of succinylcholine ( $40 \mathrm{mg}$. and $20 \mathrm{mg}$.) were given with no change in muscle tone. Intubation was accomplished with some difficulty.

Anaesthesia was maintained by a nitrous-oxide-oxygen-methoxyflurane (0.3\%) mixture. D-tubocurarine $18 \mathrm{mg}$. was given with apparently satisfactory effect, and intermittent positive pressure ventilation instituted using a Bird Mark VIII 
ventilator. The patient was placed in the prone position for operation on a scoliosis operating frame. Due to the increasing muscle tone, two supplementary doses of d-tubocurarine ( $9 \mathrm{mg}$. and $6 \mathrm{mg}$.) were administered ninety and one hundred and twenty minutes respectively after induction, but it was observed that the tonicity persisted. Blood pressure was stable at $115-125 \mathrm{~mm}$. Hg systolic; heart rate was $120-130$ per minute, and the rectal temperature was $37^{\circ} \mathrm{C} .\left(98.6^{\circ} \mathrm{F}\right.$.). Blood loss was measured during the procedure, and stored blood was given to replace losses, maintaining a normal blood balance throughout.

After the first two hours of anaesthesia the rectal temperature began to increase and within 30 minutes had risen from $37^{\circ} \mathrm{C}$. $\left(98.6^{\circ} \mathrm{F}\right.$.) to $40^{\circ} \mathrm{C}$. (104 ${ }^{\circ} \mathrm{F}$.). Ice bags were applied round the limbs but the temperature continued to rise reaching $41^{\circ} \mathrm{C}$. $\left(105.8^{\circ} \mathrm{F}\right.$.) in the following thirty minutes. Cooling was inadequate and it was decided to stop the operation, remove the patient from the frame and surround her in ice bags to control the hyperpyrexia. At this stage, her blood pressure and pulse remained at previous levels.

During rapid closure of the wound the rectal temperature rose to $42.5^{\circ} \mathrm{C}$. $\left(108.5^{\circ} \mathrm{F}\right.$.); the blood pressure dropped to $30 \mathrm{~mm}$. Hg systolic with a bradycardia of 50 per minute. There was a generalized intense muscle hypertonicity. Calcium chloride (500 mg.) and atropine $(0.6 \mathrm{mg}$.) were injected intravenously with a resulting increase in blood pressure to $80 \mathrm{~mm}$. Hg systolic and in heart rate to 76 per minute.

During the next five minutes the patient's condition deteriorated rapidly, and cardiac arrest occurred during removal from the scoliosis frame. The arrest was detected instantly and closed chest massage was instituted. The heart failed to respond satisfactorily, however, and the chest was opened. Sodium bicarbonate, calcium chloride, and intracardiac adrenaline were administered together with blood and Rheomacrodex. The heart restarted on numerous occasions and initially the myocardium had excellent tone. Subsequently, ventricular fibrillation occurred. Numerous attempts at defibrillation were unsuccessful in restoring sinus rhythm. After prolonged efforts at resuscitation the patient was pronounced dead five hours after the induction of anaesthesia. A muscle biopsy taken during operation showed no evidence of muscular disease.

\section{Discussion}

Hyperpyrexia in these three cases was primarily the result of increased heat production associated with a generalized skeletal muscle hypertonicity rather than a decreased heat loss. In each case, the operating room was between $68^{\circ}$ and $72^{\circ} \mathrm{F}$. with a relative humidity of 70 per cent.

It is known that the depolarizing muscle relaxants may precipitate an acute episode of myotonia in patients suffering from the myotonic syndrome. ${ }^{6}$ Myotonia congenita in association with hyperpyrexia during anaesthesia was reported by Saidman et al. ${ }^{2}$ In this paper each patient underwent an operation which involved an abnormal musculo-skeletal system. However, preoperatively, the strabismus in Case II and the scoliosis in Case III were not considered to be part of a generalized myopathy. Each patient had undergone previous general anaesthesia with no untoward effects. 
The control of the persistent muscle hypertonicity presents a considerable problem. General anaesthetic agents and muscle relaxants are of no value in alleviating myotonia. Intravenous quinin $e^{6}$ or a slow injection of intravenous procaine amide ${ }^{7}$ have been recommended.

Should hyperpyrexia occur, it is essential that the rapid rise in body temperature be forestalled by active cooling regardless of all other considerations. Immediate efforts should be made to halt the rising temperature by any means available during surgery and in the postoperative period. Successful rapid cooling may be achieved by pouring diethyl ether or ethyl chloride in liberal quantities directly on to the skin. ${ }^{5}$ In addition, it would seem logical to use chlorpromazine hydrochloride intravenously to maintain peripheral vasodilation and prevent shivering.

Respiratory acidosis should be treated by hyperventilation, and in view of the hyperpyrexia and raised metabolic rate, an oxygen-rich mixture should be used. Metabolic acidosis should be corrected by using sodium bicarbonate intravenously in dosages determined by serial blood gas analysis. If blood gas measurement facilities are not readily available the base excess may be assumed to be between -5 to $-10 \mathrm{mEq} . / \mathrm{L}$.

In proven or suspected cases of the myotonic syndrome, depolarizing muscle relaxants should be avoided. From a premonitory point of view, any case failing to respond normally to the administration of depolarizing muscle relaxants must be regarded with suspicion. In our experience, succinylcholine does not appear essential in the causation of this abnormal myotonic response to anaesthesia, but it may initiate or be associated with the reaction. It is reasonable that all cases undergoing general anaesthesia should receive continuous temperature monitoring for early detection of pyrexia.

\section{SUMMARY}

In this paper, three cases of hyperpyrexia occurring during general anaesthesia are reported. Their possible association with the depolarizing muscle relaxants or primary muscle disease is outlined.

The need for rigorous symptomatic treatment is emphasized, and suggested methods of management are described.

\section{RÉSUMÉ}

Nous rapportons trois cas d'hyperpyréxie survenue au cours d'une anesthésie générale. Chez ces trois malades, l'hyperpyrexie semble être le résultat primitivement d'une production de chaleur reliée à une hypertonicité généralisée des muscles squelettiques plutốt qu'à une diminution de la perte de chaleur. Dans chacun des cas, la température de la salle d'opération variait entre $68^{\circ}$ et $72^{\circ} \mathrm{F}$. et l'humidité relative était de 70 poux cent. Chacun de ces malades subissait une opération qui impliquait un système musculo-squelettique anormal. Chacun sait que les myorésolutifs dépolarisants peuvent produire une épisode aiguë de myotonie chez des malades qui souffrent d'un syndrôme myotonique. Saidman et ses associés ont déjà signalé le rapport qui existe entre la myotonie anormale congénitale et l'hyperpyrexie au cours de l'anesthésie. Chez nos malades nous ne considérons pas le strabisme du cas numéro II et la scoliose du cas numéro III 
comme faisant partie d'une myopathie généralisée. Chacun de ces malades avait eu antérieurement ou a eu subséquemment des anesthésies générales sans effets malencontreux.

Le contrôle d'une hypertonicité musculaire persistante pose un problème considérable. Les agents anesthésiques généraux et les myorésolutifs demeurent sans valeur pour soulager la myotonie.

Si l'hyperpyréxie apparait, il est essentiel, en dépit de toutes les autres considérations, de lutter contre l'élévation rapide de la température du malade par un refroidissement actif. Il faut tout mettre en œuvre pour arrêter l'élévation de la température par n'importe quels moyens au cours de la chirurgie et au cours des suites opératoires. On peut réussir à refroidir rapidement un malade en versant en grandes quantités, directement sur la peau, de l'éther diéthylique ou du chlorure d'éthyle. De plus, il semblerait logique d'administrer par voie endoveineuse du chlorhydrate de chlorpromazine pour conserver une vasodilatation périphérique et prévenir le frisson. Il faut traiter l'acidose respiratoire par l'hyperventilation et, en présence d'hyperpyrexie et d'un métabolisme de base élevé, il faut ajouter de l'oxygène. On corrige l'acidose métabolique en administrant par voie endoveineuse du bicarbonate de sodium à des doses déterminées par les analyses en série qu'il faut faire sur le sang du malade. S'il n'est pas possible d'obtenir l'analyse des gaz du sang, on peut présumer que l'excès des bases soit entre -5 et $-10 \mathrm{mEq}$. $/ \mathrm{L}$.

Si l'on est en face d'un cas de syndrome myotonique prouvé ou présumé, il faut éviter l'usage des myorésolutifs dépolarisants. D'un point de vue prémonitoire, tout malade répondant de façon anormale à l'administration de myorésolutifs dépolarisants doit être considéré comme suspect. A notre avis, l’administration de la succinylcholine n'est pas une chose essentielle pour qu'apparaisse cette réponse anormale à l'anesthésie, mais elle peut déclencher une telle réaction ou y être reliée. Il nous semble raisonnable que tous les cas qui sont soumis à une anesthésie générale puissant avoir un moniteur pour dépister précocement toute élévation de la température corporelle.

\section{ACKNOWLEDGMENTS}

We would like to thank Dr. D. A. Gibson, Dr. A. L. Morgan, and Dr. J. E. Hall of the Hospital for Sick Children, Toronto, for permission to publish details of these cases and Dr. S. Saxena for her help in the preparation of this paper.

\section{REFERENCES}

1. Stephen, C. R. Personal communication (1964).

2. Samman, L. J.; HAvard, E. S.; \& EgER, E. I. Hyperthermia during Anesthesia. J.A.M.A. 190: 1029 (1964).

3. MANN, C. T. Personal communication (1965).

4. Biclen, J. A. \& McQuiston, W. O. Body Temperatures during Anaestheisa in Infants and Children. J.A.M.A. 146; 551 (1951).

5. SMrth, R. M. Personal communication (1964).

6. Kaupman, L. Anaesthesia in Dystrophia Myotonica. Proc. Roy. Soc. Med. 53: 183 (1960).

7. Geschwind, N. \& Smpson, J. A. Procaine Amide in the Treatment of Myotonia. Brain. 78: 81 (1955). 